had at least one dose reduction and $60.0 \%$ at least one dose interruption. 9.8\% discontinued due to rucaparib toxicity and 5 pts remained on treatment upon analysis. Median PFS was 6.0 mo (95\% CI 2.5-7.8). For treatment group (19 radiologically-evaluable pts), the disease control rate was $42.0 \%$

\begin{tabular}{|c|c|c|c|}
\hline & Total $(n=51)$ & $\begin{array}{l}\text { Maintenance } \\
(\mathrm{n}=18)\end{array}$ & $\begin{array}{l}\text { Treatment } \\
(\mathrm{n}=\mathbf{3 3})\end{array}$ \\
\hline \multicolumn{4}{|l|}{ Age } \\
\hline Median & 63.0 & 65.5 & 63.0 \\
\hline Min & 36 & 44 & 36 \\
\hline $\operatorname{Max}$ & 86 & 86 & 86 \\
\hline $70 \mathrm{y}$ or older & $10(19.6 \%)$ & $4(22.2 \%)$ & $6(18.2 \%)$ \\
\hline \multicolumn{4}{|l|}{ ECOG } \\
\hline 0 & $19(37.3 \%)$ & $7(38.9 \%)$ & $12(36.4 \%)$ \\
\hline 1 & $25(49.0 \%)$ & $10(55.6 \%)$ & $15(45.5 \%)$ \\
\hline 2 & $3(5.9 \%)$ & $0(0.0 \%)$ & $3(9.1 \%)$ \\
\hline Unknown & $4(7.8 \%)$ & $1(5.6 \%)$ & $3(9.1 \%)$ \\
\hline Measurable disease & $37(72.5 \%)$ & $9(50.0 \%)$ & $28(84.8 \%)$ \\
\hline Relevant comorbidities & $17(33.3 \%)$ & $10(55.6 \%)$ & $7(21.2 \%)$ \\
\hline \multicolumn{4}{|l|}{$\begin{array}{l}\text { Rucaparib exposure } \\
\text { (months) }\end{array}$} \\
\hline Median & 4.5 & 7.9 & 2.7 \\
\hline Min & $<1$ & 1 & $<1$ \\
\hline $\operatorname{Max}$ & 30 & 30 & 18 \\
\hline \multicolumn{4}{|l|}{ Rucaparib dose (mg) } \\
\hline Median & 557.7 & 553.9 & 600.0 \\
\hline Min & 300 & 316 & 300 \\
\hline $\operatorname{Max}$ & 600 & 600 & 600 \\
\hline Dose reductions & $\mathrm{n}=50$ & $\mathrm{n}=18$ & $\mathrm{n}=32$ \\
\hline 0 & $25(50.0 \%)$ & $7(38.9 \%)$ & $18(56.3 \%)$ \\
\hline 1 & $16(32.0 \%)$ & $5(27.8 \%)$ & $11(34.4 \%)$ \\
\hline 2 & $8(16.0 \%)$ & $5(27.8 \%)$ & $3(9.4 \%)$ \\
\hline 3 & $1(2.0 \%)$ & $1(5.6 \%)$ & $0(0.0 \%)$ \\
\hline Dose interruptions & $\mathrm{n}=50$ & $\mathrm{n}=18$ & $n=32$ \\
\hline 0 & $20(40.0 \%)$ & $8(44.4 \%)$ & $12(37.5 \%)$ \\
\hline 1 & $20(40.0 \%)$ & $7(38.9 \%)$ & $13(40.6 \%)$ \\
\hline 2 & $8(16.0 \%)$ & $1(5.6 \%)$ & $7(21.9 \%)$ \\
\hline$\geq 3$ & $2(4.0 \%)$ & $2(11.2 \%)$ & $0(0.0 \%)$ \\
\hline \multicolumn{4}{|l|}{ EoT reason } \\
\hline PD & $36(70.6 \%)$ & $13(72.2 \%)$ & $23(69.7 \%)$ \\
\hline Toxicity & $5(9.8 \%)$ & $1(5.6 \%)$ & $4(12.1 \%)$ \\
\hline Other & $5(9.8 \%)$ & $1(5.6 \%)$ & $4(12.1 \%)$ \\
\hline Ongoing & $5(9.8 \%)$ & $3(16.7 \%)$ & $2(6.1 \%)$ \\
\hline
\end{tabular}

Abstract 403 Table 2 Rucaparib-related most common toxicity (per patient)

\begin{tabular}{|c|c|c|c|c|c|c|}
\hline \multirow[b]{2}{*}{ AE term (CTCAE 5.0) } & \multicolumn{2}{|l|}{$\begin{array}{l}\text { Total }(\mathrm{n}=51) \\
\mathrm{n}(\%)\end{array}$} & \multicolumn{2}{|c|}{$\begin{array}{l}\text { Maintenance }(\mathrm{n}=18) \\
\mathrm{n}(\%)\end{array}$} & \multicolumn{2}{|c|}{$\begin{array}{l}\text { Treatment }(\mathrm{n}=33) \\
\mathrm{n}(\%)\end{array}$} \\
\hline & All grades & G3-4 & All grades & G3-4 & All grades & G3-4 \\
\hline Anemia & $23(45.1)$ & $7(13.7)$ & $5(27.8)$ & $2(11.1)$ & $18(54.5)$ & $5(15.2)$ \\
\hline Thrombocytopenia & $13(25.5)$ & $3(5.9)$ & $1(5.6)$ & $0(0.0)$ & $12(36.4)$ & $3(9.1)$ \\
\hline Neutropenia & $7(13.7)$ & $3(5.9)$ & $3(16.7)$ & $0(0.0)$ & $4(12.1)$ & $3(9.1)$ \\
\hline ALT increased & $13(25.5)$ & $1(2.0)$ & $6(33.3)$ & $1(5.6)$ & $7(21.2)$ & $0(0.0)$ \\
\hline Fatigue & $13(25.5)$ & $2(3.9)$ & $6(33.3)$ & $0(0.0)$ & $7(21.2)$ & $2(6.1)$ \\
\hline Nausea & $13(25.5)$ & $1(2.0)$ & $8(44.4)$ & $1(5.6)$ & $5(15.2)$ & $0(0.0)$ \\
\hline AST increased & $12(23.5)$ & $0(0.0)$ & $7(38.9)$ & $0(0.0)$ & $5(15.2)$ & $0(0.0)$ \\
\hline Creatinine increased & $7(13.7)$ & $0(0.0)$ & $6(33.3)$ & $0(0.0)$ & $1(3.0)$ & $0(0.0)$ \\
\hline Hyponatremia & $7(13.7)$ & $2(3.9)$ & $0(0.0)$ & $0(0.0)$ & $7(21.2)$ & $2(3.9)$ \\
\hline ALP increased & $6(11.8)$ & $2(3.9)$ & $2(11.1)$ & $1(5.6)$ & $4(12.1)$ & $1(3.0)$ \\
\hline Diarrhea & $6(11.8)$ & $0(0.0)$ & $5(27.8)$ & $0(0.0)$ & $1(3.0)$ & $0(0.0)$ \\
\hline Abdominal pain & $5(9.8)$ & $1(2.0)$ & $3(16.7)$ & $0(0.0)$ & $2(6.1)$ & $1(3.0)$ \\
\hline Vomiting & $5(9.8)$ & $2(3.9)$ & $2(11.1)$ & $0(0.0)$ & $3(9.1)$ & $2(3.9)$ \\
\hline Asthenia & $4(7.8)$ & $0(0.0)$ & $1(5.6)$ & $0(0.0)$ & $3(9.1)$ & $0(0.0)$ \\
\hline Dysgeusia & $4(7.8)$ & $0(0.0)$ & $3(16.7)$ & $0(0.0)$ & $1(3.0)$ & $0(0.0)$ \\
\hline Pruritus & $4(7.8)$ & $0(0.0)$ & $3(16.7)$ & $0(0.0)$ & $1(3.0)$ & $0(0.0)$ \\
\hline Constipation & $3(5.9)$ & $0(0.0)$ & $1(5.6)$ & $0(0.0)$ & $2(6.1)$ & $0(0.0)$ \\
\hline Colonic obstruction & $1(2.0)$ & $1(2.0)$ & $0(0.0)$ & $0(0.0)$ & $1(3.0)$ & $1(3.0)$ \\
\hline GGT increased & $1(2.0)$ & $1(2.0)$ & $1(5.6)$ & $1(5.6)$ & $0(0.0)$ & $0(0.0)$ \\
\hline Intestinal obstruction & $1(2.0)$ & $1(2.0)$ & $0(0.0)$ & $0(0.0)$ & $1(3.0)$ & $1(3.0)$ \\
\hline Pleural effusion & $1(2.0)$ & $1(2.0)$ & $0(0.0)$ & $0(0.0)$ & $1(3.0)$ & $1(3.0)$ \\
\hline $\begin{array}{l}\text { Myelodysplastic } \\
\text { syndrome }\end{array}$ & $1(2.0)$ & $1(2.0)$ & $0(0.0)$ & $0(0.0)$ & $1(3.0)$ & $1(3.0)$ \\
\hline
\end{tabular}

(21.0\% PR and $21.0 \%$ SD). Overall, $86.3 \%$ of pts had rucaparib-related toxicities, while most common G3-4 hematological events were anemia (13.7\%), neutropenia (5.9\%), and thrombocytopenia (5.9\%).

Conclusion* Rucaparib's safety profile in real-life setting is manageable and efficacy results, even considering heavily pretreated pts, are comparable to those of previous trials. The RAP in Spain showed a consolidated management of rucaparib and, consequently, an improved safety profile.

\section{OVARIAN CANCER METASTASES IN THE LIVER AREA: PROPOSAL OF A STANDARDIZED ANATOMO-SURGICAL CLASSIFICATION}

A Rosati*, AM De Rose, G Avesani, F Giuliante, G Scambia, A Fagotti. Fondazione Policlinico A. Gemelli. IRCCS, Rome, Italy

\subsection{6/ijgc-2021-ESG0.399}

Introduction/Background* The combination of emerging target therapies and continuous technological advancement in surgical procedures support a trend toward a prolonged survival in advanced ovarian cancer (AOC) patients. Upper abdominal carcinomatosis hides challenging locations for complete gross resection in the hands of expert gynecologic oncologists. We developed an anatomo-surgical classification for ovarian cancer metastases in the liver area from a gynecological point of view, aiming to provide an anatomo-topographical tool to address each surgical task and to standardize the nomenclature in the radiological and surgical report.

Methodology After the identification of four conceptually distinct anatomical areas, we used both the three-dimensional anatomical model and the surgical video report to represent them individually.

Result(s)* Our anatomo-surgical classification is divided into 4 distinct categories:

TYPE1 GLISSON'S CAPSULE: superficial metastases involving only the Glisson's sheat with no parenchymal infiltration (either focal or extensive).

TYPE2 LIGAMENTOUS: this is a heterogeneous group defining cancer deposits along the lines of reflection between the liver and surrounding organs. We can further divide it into 'falciform ligament', 'round ligament', 'Arantii and hepato-gastric ligament', 'coronary and triangular ligament' localizations.

TYPE3 HEPATIC HILUM: the porta hepatis is considered as a single entity due to its potentially dual neoplastic involvement both peritoneal or 'external' as hepato-duodenal ligament and lymphatic or 'internal' while involving lymph-nodes along the portal triad.

TYPE4 PARENCHYMAL: we identified, based on surgical management, the 'superficial' intra-parenchymal localization, infiltrating the less than $1 \mathrm{~cm}$ in depth, and the fully intraparenchymal.

Conclusion* Our classification represents a useful guide while planning the surgical strategy to AOC metastases in the liver area.

Identification of each category, specific underlining anatomical pitfalls and its surgical-related management, guarantees a didactic and effective tool in supporting the daily intraoperative decision-making algorithm, and in assigning the specific procedure within a multidisciplinary team, based on surgical competence. 
Furthermore, the standardization of nomenclature allows an easy exchange of surgical information for scientific purposes, that are otherwise difficult to interpret and compare.

\section{SURGERY FOR MALIGNANT OVARIAN GERM CELL TUMOURS: A MULTICENTRE RETROSPECTIVE COHORT STUDY}

${ }^{1} \mathrm{R}$ Graham*, ${ }^{1} \mathrm{~N}$ Macdonald, ${ }^{2} \mathrm{~K}$ Murali, ${ }^{3} \mathrm{~S} J$ Sarker, ${ }^{1} \mathrm{R}$ Miller, ${ }^{2} \mathrm{~S}$ Banerjee, ${ }^{2} \mathrm{~J}$ Butler, ${ }^{1} \mathrm{~S}$ Stoneham, ${ }^{4} \mathrm{~J}$ Shamash, ${ }^{1} \mathrm{~V}$ Liberale, ${ }^{4} \mathrm{D}$ Berney, ${ }^{5} \mathrm{M}$ Lockley, ${ }^{6} \mathrm{C}$ Newton. ${ }^{1}$ University College Hospital, UK; ${ }^{2}$ The Royal Marsden Hospital, UK; ${ }^{3}$ University College London, UK; ${ }^{4}$ St Bartholomew's Hospital, UK; ${ }^{5}$ Queen Mary University of London, UK; ${ }^{6}$ University Hospitals Bristol and Weston NHS Foundation Trust, UK

10.1136/ijgc-2021-ESG0.400
Introduction/Background* Malignant ovarian germ cell tumours (MOGCTs) are rare with a yearly-adjusted incidence of 3.7 per million [1] and account for $1-2 \%$ of all ovarian malignancies in Europe. There is a clinical imperative to clarify the optimal surgical approach and establish surgical radicality since this is a predominantly young population and minimising treatment morbidity and optimising future fertility is of real importance. Here we aim to describe the current surgical management of ovarian germ cell tumours and relate this to clinical outcome. Specifically, we aimed to compare outcomes of open versus laparoscopic surgery, the use of fertility-sparing approaches, surgical staging, and the potential utility of cystectomy alone in the management of patients with stage 1 immature teratoma.

Methodology A retrospective cohort study of all consecutive patients with primary ovarian germ cell tumours treated in four major UK gynaecology oncology centres over 12 years.

\section{Abstract 414 Table 1}

\begin{tabular}{|c|c|c|c|c|c|c|}
\hline & $\begin{array}{l}\text { All } \\
\text { pathologies }\end{array}$ & Dysgerminoma & $\begin{array}{l}\text { Yolk sac } \\
\text { tumour }\end{array}$ & $\begin{array}{l}\text { Mixed germ cell } \\
\text { tumour }\end{array}$ & $\begin{array}{l}\text { Immature } \\
\text { teratoma }\end{array}$ & $\begin{array}{l}\text { Primitive neuroectodermal } \\
\text { tumour }\end{array}$ \\
\hline Total, N (\%) & $137(100.0)$ & $37(27.0)$ & $23(16.8)$ & $29(21.1)$ & $44(32.1)$ & $4(2.9)$ \\
\hline \multicolumn{7}{|l|}{ FIGO 2014 stage } \\
\hline Stage 1 & $86(62.3)$ & $24(64.9)$ & $13(56.5)$ & $10(34.5)$ & $39(88.6)$ & $0(0.0)$ \\
\hline Stage 2 & $11(8.0)$ & $2(5.4)$ & $2(8.7)$ & $6(20.7)$ & $0(0.0)$ & $1(25.0)$ \\
\hline Stage 3 & $23(16.7)$ & $6(16.2)$ & $7(30.4)$ & $7(24.1)$ & $1(2.3)$ & $2(50.0)$ \\
\hline Stage 4 & $15(10.9)$ & $4(10.8)$ & $1(4.3)$ & $6(20.7)$ & $3(6.8)$ & $1(25.0)$ \\
\hline \multicolumn{7}{|l|}{ Age } \\
\hline Median (IQR) & $23(14)$ & $21(10)$ & $27(13)$ & $23(14)$ & $26(15.5)$ & $23(11.75)$ \\
\hline$<18, \mathrm{~N}(\%)$ & 31 (22.6) & $10(27.0)$ & $3(13.0)$ & $3(10.3)$ & $14(31.8)$ & $1(25.0)$ \\
\hline$>18, \mathrm{~N}(\%)$ & $106(77.3)$ & $27(73.0)$ & $20(87.0)$ & $26(89.7)$ & $30(68.2)$ & $3(75.0)$ \\
\hline \multicolumn{7}{|l|}{ Surgical route } \\
\hline Laparotomy & $109(80.0)$ & $23(62.1)$ & $21(91.3)$ & $25(86.2)$ & $36(81.8)$ & $4(100.0)$ \\
\hline Laparoscopy & $22(16.0)$ & $11(8.0)$ & $2(8.7)$ & $2(6.9)$ & $7(5.1)$ & $0(0.0)$ \\
\hline \multicolumn{7}{|l|}{ Surgery type } \\
\hline Fertility sparing & $120(87.6)$ & $31(83.8)$ & $22(95.7)$ & $24(82.8)$ & $40(90.9)$ & $3(75.0)$ \\
\hline Non-fertility sparing & $16(11.7)$ & $6(16.2)$ & $1(8.7)$ & $4(13.8)$ & $4(9.1)$ & $1(25.0)$ \\
\hline Primary debulking & 10 & 1 & 1 & 4 & 1 & 1 \\
\hline Interval debulking & 5 & 2 & 0 & 0 & 3 & 0 \\
\hline Prophylactic surgery & 3 & 3 & 0 & 0 & 0 & 0 \\
\hline \multicolumn{7}{|l|}{ Chemotherapy } \\
\hline None & $61(44.5)$ & $15(40.5)$ & $4(17.4)$ & $9(31.0)$ & $33(75.0)$ & $0(0.0)$ \\
\hline Neoadjuvant & $16(11.7)$ & $7(18.9)$ & $2(8.7)$ & $2(6.9)$ & $4(9.1)$ & $1(25.0)$ \\
\hline Adjuvant & $60(43.8)$ & $15(40.5)$ & $17(73.9)$ & $18(62.1)$ & $7(15.9)$ & $3(75.0)$ \\
\hline \multicolumn{7}{|l|}{ Residual disease } \\
\hline none & $112(81.8)$ & $35(94.6)$ & $14(60.9)$ & $21(72.4)$ & $39(88.6)$ & $3(75.0)$ \\
\hline$<1 \mathrm{~cm}$ & $4(2.9)$ & $0(0.0)$ & $2(8.7)$ & $1(3.4)$ & $1(2.3)$ & $0(0.0)$ \\
\hline$>1 \mathrm{~cm}$ & $20(14.6)$ & $2(5.4)$ & $7(30.4)$ & $6(20.7)$ & $4(9.1)$ & $1(25.0)$ \\
\hline \multicolumn{7}{|l|}{ Completion surgery } \\
\hline performed & $11(8.0)$ & $1(2.7)$ & $4(17.4)$ & $2(6.9)$ & $4(9.1)$ & $0(0.0)$ \\
\hline not performed & $124(90.5)$ & $36(97.3)$ & $19(82.6)$ & $26(89.7)$ & $39(88.6)$ & $4(100.0)$ \\
\hline Recurrence & $39(28.5)$ & $3(8.1)$ & $8(34.8)$ & $15(51.7)$ & $9(20.5)$ & $4(100.0)$ \\
\hline \multicolumn{7}{|l|}{ Time to recurrence (days) } \\
\hline median (IQR) & $211(249)$ & $363(1398.5)$ & $153(296.25)$ & $174(126.5)$ & $212(208)$ & 367.5 (368.75) \\
\hline \multicolumn{7}{|l|}{ Censor outcome } \\
\hline Dead & $10(7.3)$ & $0(0.0)$ & $3(13.0)$ & $5(17.2)$ & $0(0.0)$ & $2(50.0)$ \\
\hline Alive with disease & $3(2.2)$ & $0(0.0)$ & $1(0.0)$ & $0(0.0)$ & $1(2.2)$ & $1(25.0)$ \\
\hline Alive and disease free & $127(17.5)$ & $37(100.0)$ & $20(87.0)$ & $24(82.8)$ & $43(97.7)$ & $1(25.0)$ \\
\hline \multicolumn{7}{|l|}{$\begin{array}{l}\text { Time to censor outcome } \\
\text { (years) }\end{array}$} \\
\hline median (IQR) & $4.6(4.6)$ & $6.0(3.2)$ & $4.9(4.6)$ & $4.9(5.2)$ & $3.2(3.4)$ & $1.3(1.6)$ \\
\hline
\end{tabular}

